\title{
Development of Chhana Spread Prepared with Moringa Leaves Extract (Yield)
}

\author{
Alok Rai", M. P. S. Yadav, Samar Jeet Singh and Hari Shanker \\ Department of AH \& Dairying, C S Azad University of Agriculture \& Technology, \\ Kanpur, UP, India \\ *Corresponding author
}

\section{A B S T R A C T}

Keywords

Moringa leaves extract, Cow milk chhana, Lactic acid, Calcium lactate, Salt, Yield.

\section{Article Info}

\section{Accepted:}

10 January 2021

Available Online:

10 February 2021
The present investigation was an attempt to Development of Chhana spread prepared with moringa leaves extract was prepared by the using of cow milk with $0 \%, 5 \%, 10 \%, 15 \%$ and $20 \%$ moringa leaves extract, Lactic acid and calcium lactate were used as coagulants, three levels of salt $1 \%, 1.5 \%$, and $2 \%$. The prepared samples were stored at refrigeration temperature $\left(5^{0} \mathrm{C}\right)$ for $0,10,20$ and 30 days. The fresh and stored samples were analysed for their yield. The cost of production was also determined. The overall maximum yield obtained in case of Chhana Spread prepared from calcium lactate coagulant with $2 \%$ salt. Considering the medicinal and nutritional importance of Chhana spread this technology can be used in commercial scale basis.

\section{Introduction}

India has emerged as the largest milk producer in the world with a record production level of 188.00 million tons during 2019-20.and the importance of milk and milk product in India has been recognized since Vedic times (five thousand years ago).

The significant portion of milk produced in India is covered into a variety of indigenous milk products.

Among milk products, chhana is gaining momentum in its production and consumption. Chhana is heat and acid coagulated Indigenous milk products which forms the base of several popular Indian sweets like Rasogulla, Sandesh, Rasmalai and Chumchum etc. It is also used as base material for the preparation of large number dishes. It originated in eastern part of the country particularly from west Bengal, but now a day it is also popular in north western region of India.

Chhana means the product obtained from cow milk by precipitation with sour milk, lactic acid or citric acid. It shall not contain more than 65 per cent moisture and the milk fat 
content shall not be less than 50 per cent of the dry matter (Food safety and standard act).

Shelf-life of milk product is also one of the most important factors for its production on commercial scale. Shelf life of chhana has been reported to be about 12 days at $7^{\circ} \mathrm{C}$ and 3 days at $24^{0} \mathrm{C}$ respectively (De and Ray: 1953).

Moringa oleifera belonging to the family of Moringaceae is an effective remedy for malnutrition. Moringa is rich in nutrition owing to the presence of a variety of essential phytochemicals present in its leaves, pods and seeds. In fact, moringa is said to provide 7 times more vitamin $\mathrm{C}$ than oranges, 10 times more vitamin A than carrots, 17 times more calcium than milk, 9 times more protein than yoghurt, 15 times more potassium than bananas and 25 times more iron than spinach.(Rockwood et al, 2013).

\section{Materials and Methods}

Materials mainly included the ingredients required for optimization of compositional and processing parameters of Chhana spread. These were:-

\section{Whole milk}

Requisite amount of cow milk was obtained from Experimental Dairy C.S. Azad University of Agriculture \& Technology, Kanpur and was standardized at 3.5 per cent fat level for the preparation of chhana spread with moringa leaf extract.

\section{Moringa oleifera leaves extract}

Leaves extract was used as a raw material for the preparation of Moringa Paneer. The extract was prepared by following method. First the fresh and clean leaves of Moringa oleifera were dehydrated at room temperature in an incubator. For preparing $100 \mathrm{ml}$ extract, weighed accurately $25 \mathrm{~g}$ of dehydrated leaves, then boiled them for 5 minutes in water and after cooling, finely ground them in grinder for obtaining a fine paste. This paste was collected in a muslin cloth and tied then gently pressed by applying a suitable pressure until whole juice was extracted. Thus a clear extract was obtained.

\section{Coagulants}

In this study lactic acid and calcium lactate were used for the preparation of chhana spread.

\section{Common salt: Tata salt.}

\section{Packaging material}

Polystyrene cups of $100 \mathrm{~g}$ capacity were used for packing of chhana spread.

\section{Manufacturing technology}

The required amount of cow milk was standardized to $3.5 \%$ fat and $8.5 \% \mathrm{SNF}$ as per method suggested by Ray and De (1953). Adding different amount of Moringa leaves extract e.g. $0 \%, 5 \%, 10 \%, 15 \%$, and $20 \%$ cow milk respectively at $61-63^{\circ} \mathrm{C}$ temperature. After addition of extract the cow milk was heated at $80^{\circ} \mathrm{C}$ for $15 \mathrm{~min}$. During heating proper stirring was maintained by a stainless steel ladle to avoid burning and to prevent skin formation. 1.5 per cent solution of lactic acid and calcium lactate was added to cow milk at $70^{\circ} \mathrm{C}$. The milk was gently stirred to obtain coagulated curd clear whey. After coagulation traditional method was used to drain the free whey from the coagulated mass. The curd along with whey was transferred on a muslin cloth and whey was allowed to drain by hanging technique till trickling of free whey was stopped. The curd sample obtained by this method was subjected for chhana spread making. The curd from traditional 
method was converted into chhana spread by using method suggested by Tiwari and Sachdeva (1991). In this case chhana was broken into pieces and blended in domestic blender along with 10 per cent whey and specified salt levels e.g. $1 \%, 1.5 \%$ and $2.0 \%$. There after the samples were packed in plastic cups and stored at refrigeration temperature $\left(5^{\circ} \mathrm{C}\right)$.

Flow diagram of manufacture of Chhana spread prepared with Moringa Leaf Extract

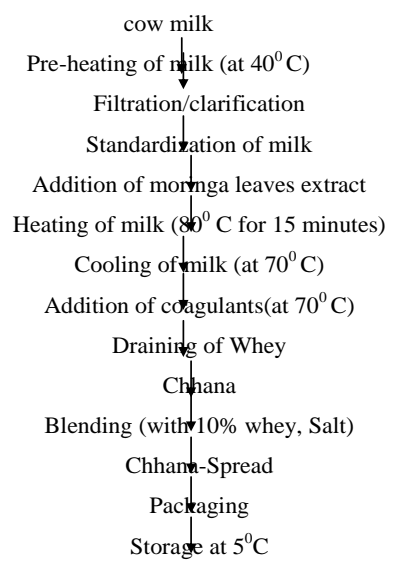

\section{Results and Discussion}

The yield of Chhana Spread as affected by different factors has been presented in Table 1(A) and 1(B).
From table 1 (A) As regards the mean values of yield of Chhana Spread, it was observed that maximum yield $(20.20 \%)$ was in $\mathrm{A}_{5}$ samples followed by $\mathrm{A}_{4}, \mathrm{~A}_{3}$ samples, while lowest yield (19.15\%) was noted in $A_{1}$ samples. The significant differences were observed in between $A_{1}, A_{2}, A_{3}, A_{4} A_{5}$ samples when compared with $\mathrm{CD}$ at $5 \%$ (0.243).

As regards the mean values of yield of Chhana Spread, it was observed that maximum yield $(21.15 \%)$ in case of $\mathrm{B}_{2}$ samples, while minimum yield $(18.13 \%)$ in $\mathrm{B}_{1}$ samples. The significant differences were observed between $\mathrm{B}_{1}, \mathrm{~B}_{2}$ samples when compared with $\mathrm{CD}$ at $5 \%(0.154)$.

The effect of salt level (C) on yield of Chhana Spread, it was revealed that maximum yield $(20.20 \%)$ in case of sample prepared with $1 \%$ salt $\left(\mathrm{C}_{3}\right)$ and minimum yield (19.07\%) observed in $\mathrm{C}_{1}$ samples.

Among the treatment combinations of moringa leaves extract and types of coagulant (A.B) on yield of Chhana Spread, the maximum $(21.77 \%)$ and minimum $(17.70 \%)$ yield were observed in $\mathrm{A}_{5} \mathrm{~B}_{2}$ and $\mathrm{A}_{1} \mathrm{~B}_{1}$ combinations, respectively (Table 2 and 3 ).

Table.1 The effect of moringa leaves extract (A), coagulants (B) and level of salt (C) on yield $(\%)$ of Chhana Spread

\begin{tabular}{|l|l|l|l|l|l|l|}
\hline & B1 & B1 & C1 & C2 & C3 & Mean \\
\hline A1 & 17.70 & 20.60 & 18.65 & 19.15 & 19.65 & 19.15 \\
\hline A2 & 17.87 & 20.80 & 18.80 & 19.35 & 19.85 & 19.33 \\
\hline A3 & 18.13 & 21.13 & 19.05 & 19.65 & 20.20 & 19.63 \\
\hline A4 & 18.33 & 21.43 & 19.30 & 19.90 & 20.45 & 19.88 \\
\hline A5 & 18.63 & 21.77 & 19.55 & 20.20 & 20.85 & 20.20 \\
\hline B1 & & & 17.52 & 18.18 & 18.70 & 18.13 \\
\hline B2 & & & 20.62 & 21.12 & 21.70 & 21.15 \\
\hline Mean & 18.13 & 21.15 & 19.07 & 19.65 & 20.20 & \\
\hline
\end{tabular}


Table.2 The mean effect of ABC on yield (\%) of chhana spread

\begin{tabular}{|l|l|l|l|}
\hline & C1 & C2 & C3 \\
\hline A1B1 & 17.20 & 17.70 & 18.20 \\
\hline A1B2 & 20.10 & 20.60 & 21.10 \\
\hline A2B1 & 17.30 & 17.90 & 18.40 \\
\hline A2B2 & 20.30 & 20.80 & 21.30 \\
\hline A3B1 & 17.50 & 18.20 & 18.70 \\
\hline A3B2 & 20.60 & 21.10 & 21.70 \\
\hline A4B1 & 17.70 & 18.40 & 18.90 \\
\hline A4B2 & 20.90 & 21.40 & 22.00 \\
\hline A5B1 & 17.90 & 18.70 & 19.30 \\
\hline A5B2 & 21.20 & 21.70 & 22.40 \\
\hline
\end{tabular}

Table.3 SE(m), SE(d) AND CD

\begin{tabular}{|l|l|l|l|l|l|l|l|}
\hline & A & B & C & AB & AC & BC & ABC \\
\hline SE(m) & O.086 & 0.054 & 0.0676 & 0.122 & 0.149 & 0.094 & 0.221 \\
\hline SE(d) & 0.122 & 0.077 & 0.094 & 0.172 & 0.211 & 0.133 & 0.298 \\
\hline CD & 0.243 & 0.154 & 0.188 & N.S. & N.S. & N.S. & N.S. \\
\hline
\end{tabular}

From the mean interactions of A.C, It was observed that the maximum $(20.85 \%)$ and minimum $(18.65 \%)$ yield were in case of $\mathrm{A}_{5} \mathrm{C}_{3}$ and $\mathrm{A}_{1} \mathrm{C}_{1}$ combinations, respectively.

The effect of types of coagulant and levels of salt (B.C) on yield of Chhana Spread, It was observed that maximum yield $(21.70 \%)$ in case of $\mathrm{B}_{2} \mathrm{C}_{3}$ combinations, while minimum $(17.52 \%)$ were noted in $\mathrm{B}_{1} \mathrm{C}_{1}$ combinations.

From Table 1(B), the combined effect of moringa leaves extract, types of coagulant and levels of salt (ABC) on yield of Chhana spread, it was revealed that maximum yield (22.40\%) in case of $\mathrm{A}_{5} \mathrm{~B}_{2} \mathrm{C}_{3}$ sample followed by the combination of $\mathrm{A}_{5} \mathrm{~B}_{2} \mathrm{C}_{3}$ and $\mathrm{A}_{4} \mathrm{~B}_{2} \mathrm{C}_{2}$ which were statistically at par, while minimum Moisture (17.20\%) was noted in $\mathrm{A}_{1} \mathrm{~B}_{1} \mathrm{C}_{1}$ sample.

In conclusion the data obtained on the basis of yield \% of Chhana Spread prepared from different levels of moringa leaves extract, different coagulants and different levels of salt with storage periods have been concluded as regards the yield of Chhana Spread maximum yield $(22.40 \%)$ was noted in case of samples prepared with calcium lactate. The calcium lactate coagulant showed lowest cost of production. It is therefore, concluded that $15 \%$ moringa leaves extract can be easily mixed in milk to produce good quality Chhana Spread with calcium lactate which can be nutritional importance.

\section{References}

De, S. and Ray, S.C; (1954).Studies on the indigenous method of chhana making. Indian J. Dairy Science.7 (3): 113-115.

Kailappan R., Varadharaju N., Karunanithy C. (2007). Studies on development of kneader and ball former for chhana in rasogolla production. J. Food Engineering. 81(2): 298-305.

KhanShahnawaz Umer and Mohammad Ashraf. (2011). Paneer production: A 
review Journal of Food Science and Technology. 2011 Dec; 48(6): 645-660.

Shughanya, R. and Lalitha. (2017). Preparation of Paneer from Coconut milk, its Quality, Characteristics and shelf life. International J. of Recent Scientific Research. 8(3):16053-16057.

Sandeep, G., Anitha, T., Vijayalath, K.R. and Sadasakthi, A. (2019). Moringa for nutritional security (Moringa oleifera
Lam.). International J. Botany Studies. 4(1): 21-24.

Saravanakumaran, R., Sekhar, C. and Murugesan, S. (2019). Value Addition, Nutritional Parameters and Quality Certifications in Exportable Organic Moringa Produce. International J. of current Microbiology and Applied sciences. 8(1): 813-828.

\section{How to cite this article:}

Alok Rai, M. P. S. Yadav, Samar Jeet Singh and Hari Shanker. 2021. Development of Chhana Spread Prepared with Moringa Leaves Extract (Yield). Int.J.Curr.Microbiol.App.Sci. 10(02): 888-892. doi: https://doi.org/10.20546/ijcmas.2021.1002.104 